\title{
The Institutional Strategy in Increasing Publication Performance
}

\author{
Eriana Astuty \\ Student of Management Science \\ Doctoral Program, UPI \\ Faculty of Business and Management, \\ Universitas Widyatama, Bandung \\ eriana.astuty@gmail.com
}

\author{
Alfi Nura \\ Student of Management Science \\ Doctoral Program, UPI \\ Faculty of Economics and Business, \\ Universitas Negeri Medan, Medan \\ avi_abraar@yahoo.com
}

\author{
Muji Gunarto \\ Student of Management Science \\ Doctoral Program, UPI \\ Faculty of Economics and Business, \\ Universitas Bina Darma, Palembang \\ mgunarto@binadarma.ac.id
}

\begin{abstract}
Reputable colleges will have a good value in the eyes of its stakeholders. One indicator of the value of a college achievement is the number of scientific publications both nationally and internationally. Currently, total of publication in Indonesia is still very far behind Malaysia and Singapore, and only slightly above the Philippines. This phenomenon contradicts with the fact about total of publication in Widyatama University, at the last 18 years has increased. The authors are interested to conduct further research in order to obtain the empirical evidence so that it could give the vision on the practical implications for several other universities in increasing the institution's value. This research method is passed qualitatively by straight observation and directly interviews with some key informants. The data analysis technique using SWOT analysis has done. This study shown that Widyatama University is very serious with the faculty publications. Empirically, two main factors are emphasized in improving the Widyatama University's publication performance, are favorable government and abundant resources. Finally, the suitable strategy to adopt in this institution for the future is "grow and build strategy" to maintain and even improve the performance of Widyatama's University publication.
\end{abstract}

\section{Keywords-Publication Performance, SWOT Analysis,} Institutional Strategy

\section{INTRODUCTION}

Nowadays, the value of the higher education becomes the important factor in determining the superior performance of the university. The value of higher education among others can be seen in terms of the quality of graduates that have been produced. The number of successful research is published in both the scientific meeting of national/international as well as in publishing scientific articles (journals) national/ international. In addition, the value of a college can also be measured from the successful technology transfer that carried out by the institution for comprehensive welfare society (community service).

One of the university's values considered as an important factor is research productivity. Since considered as an indicator of personal achievement, published paper becomes an important aspect of the research productivity of the faculty, even a college [1]. Related published papers, in fact, the performance of research publications in Indonesia is still far behind compared to neighboring countries that are members of the ASEAN countries, namely Malaysia and Singapore, but were slightly above the Philippine state [2]. This can be seen in this figure below:

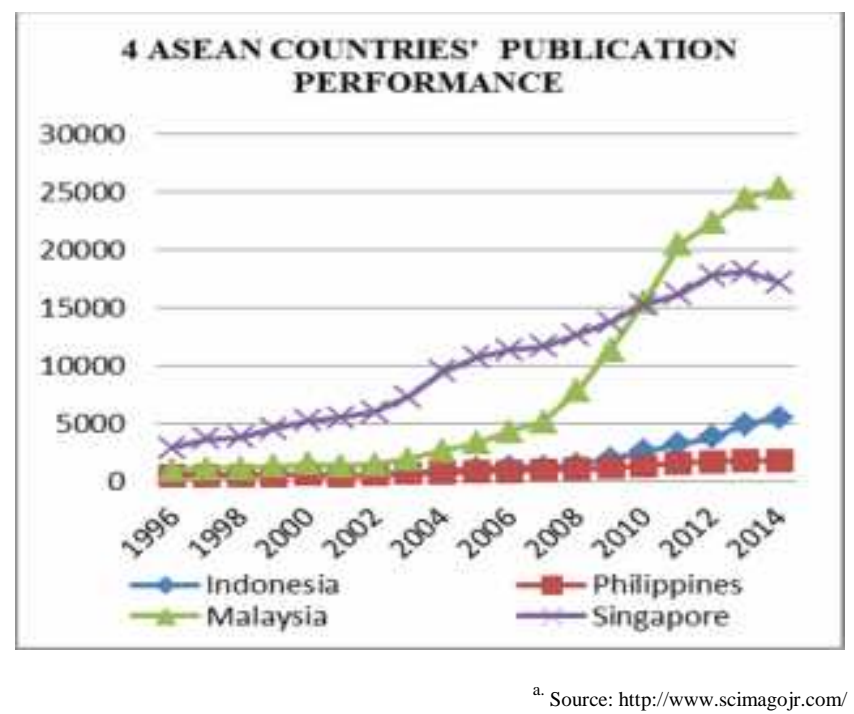

Fig. 1. Indonesia publication's performance among 4 ASEAN Countries

Additionally, related with urgency of the published paper problem in Indonesia that still low compared to other ASEAN countries, a phenomenon that appeared in the Widyatama University contradicts with the empirical facts of the overall performance of publications in Indonesia today. In the last 18 years at the Widyatama University, an increasing number of faculty publications has been happened, were causing on the rise of webometric ranking at Widyatama University in recent years. This clearly reinforces the suggestion that both the total number of highly cited Articles per scientist (HCAs), and the ratio of whole HCA publications produced a college, both today become one of the determining ranking research institution [3], 
as was done by the world rating's agencies, webometric [4]. As for the overall picture of publication performance at the Widyatama University that has increased in the last 18 years, can be seen in the image below:

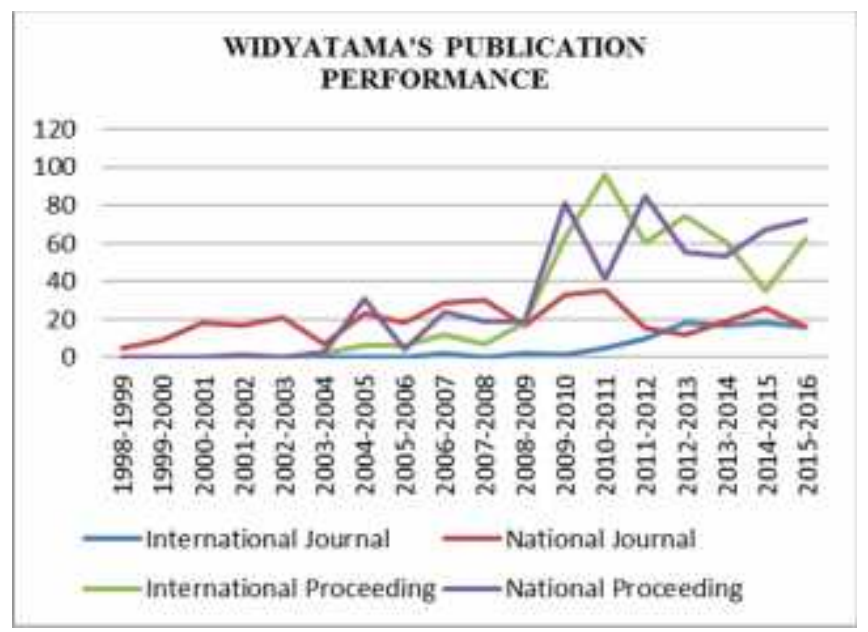

b. Source: Primary Data from Widyatama Universitas Library

Fig. 2. Widyatama Publication's Performance at 18 years latest

Based on the description above, the author is very interested in observing explorative to obtain in-depth information related to the increase of scientific publications that occurred at the Widyatama University in the last 18 years, which in turn is expected to increase the value of Widyatama University current and future.

The author proposes some of the problem in this study, namely: (1) Identifying the factors that affect the performance of publications at the Widyatama University, both internally and externally. (2) Knowing the position of institutional's publication performance currently. (3) Developing the institutional's strategy in the future related to the position of publication's performance right now.

For the big scope, the authors are interested to describe this study's finding clearly so that it could give the vision on the practical implications for several other universities in increasing the institution's value.

\section{THE PUBLICATION PERFORMANCE AS A VALUE OF A HIGHER EDUCATION}

\section{A. Research and Publication}

Research Activity is the production process that involving human, tangible resources, and intangible resources; where the output of that activity consists of tangible nature and intangible nature [5]. Tangible resources like scientific instrument, material, etc. Intangible resources among others accumulated knowledge, social networking, etc. Tangible nature like publication, patens, conference presentation, database, protocols, etc. Intangible nature among others tacitknowledge, consulting activity, etc.

In Indonesia, Research and Development Institution, classified into five types [10] among others: (1) Universities or Higher-Education Institutions (HEI's), (2) Public R\&D Institutions, which isn't affiliated with any ministry directly but funded by the government, (3) R\&D Agencies within a ministry, (4) R\&D units within industrial or business firms, and (5) R\&D Agencies formed as state-owned enterprises [11], [12]. In this study, the research examined only limited research in universities or HEIs.

Variety of outputs from research productivity, among others: books, patents, inventions, databases, and also published paper [6]. Published Paper, since viewed as an indicator of personal achievement starts to become an important aspect of research productivity [1]. The Publication effects to many things and also many stakeholders of the institution. Some benefits from publication among others: creation of new knowledge, stimulates modernization and innovation, enhance the quality of academic staff, increase an institution's reputation, and improve the economic status of the institution [7].

Research and publications provide many positive effects, both individuals and institutions. Many things led to desire authors in conducting research and publications, among others, the desire to develop themselves and the desire to get a promotion at work [8].

There are so many things can do to improve research productivity and publications, including through cooperation with professional network [6]. Not purely for research, but also for publication needs cooperation with the professional network. Particularly in international publication, some of author conduct the cooperation with professional network like the teachers/lecturers of English as a professional translator to do international publication of research that has been done [9].

\section{B. SWOT Analysis as Strategy Formulation Tools}

SWOT is an acronym for strengths, weaknesses, opportunities and threats. One of the tools used to create a strategic plan is a SWOT analysis. Using SWOT analysis, a firm could identify its environment both internal or external factors that impact to the formulation strategy of the firm. The SWOT Technique is credited to Albert Humphrey. He leads a research project at Stanford University in the 1960s and 1970s using data from Fortune 500 companies.

At all the business stages in the company, the strategic objectives of the company, all the action plans that has been planned until the operational process had its strength and weaknesses, opportunities and threats. Using SWOT Anaysis, the firm could maximize its strength and opportunity or combine both of that, could transform weaknesses into strengths, or could minimize threats, and to take advantage of opportunities along with minimizing both internal weaknesses and external threats [13]. 
SWOT analysis is an identification the various factors to formulate the corporate strategy [14]. The analysis is based on the logic that will maximize strengths, opportunities, weaknesses and threats. There are four phases to use SWOT analysis [15], are (1) Doing initial assessment, (2) indicator selection (3) collects the data (4) doing analysis and report.

Strategic decision-making process is regularly associated to the development of the mission, goals, strategic and corporate policy, which is always referred in the SWOT analysis. There are 3 (three) stages of the process of strategic planning, namely (1) the data collection phase, (2) the analysis phase, (3) the stage of decision-making.

TABLE I. THREE STAGES OF STRATEGIC FORMULATION USING SWOT ANALYSIS

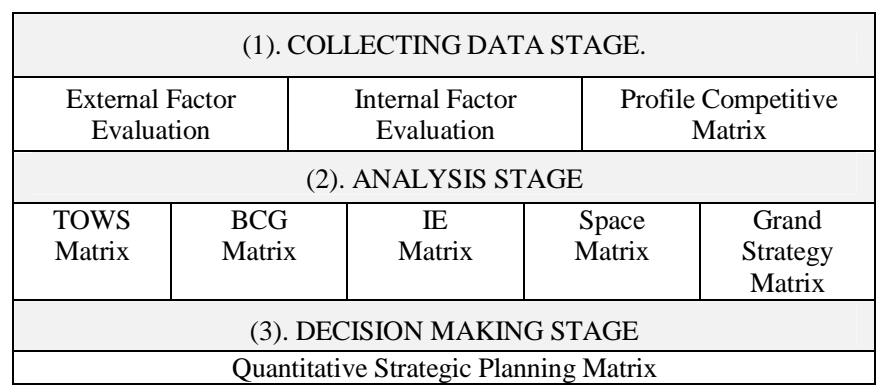

c. Source: Rangkuty, 2015

\section{RESEARCH METHODOLOGY}

This study used a qualitative descriptive design to explain the state of the subject or object of research at the moment based on facts that appear or as it is without intending to generally accepted conclusions or generalizations. This study also included exploratory research to obtain in-depth information related to the increase in the value of higher education and the preparation of several alternative strategies to increase faculty scientific publications that can be implemented through theoretical study and practical.

The research location is determined intentionally (purposive) at the Widyatama University considering that in the last 18 years have increased the number of faculty publications. The primary data collection techniques conducted using purposive sampling technique. The author conducted in-depth interviews to the key informants who were considered very understanding about the state of the performance of research and publications in Widyatama University and also the author observed the documents that exist. The question posed was developed previously and guided using a questionnaire. Secondary data were obtained from different parties such as the Widyatama University library's collection, webometrics' site, Scimagojr's site, Dikti's site and varying sources related to scientific publications.

Data analysis techniques started with environmental scanning using SWOT Analysis. Some of the strength, weaknesses, opportunity, and threats of Widyatama University are identified. This step is intended to identify things into strengths and weaknesses of the internal environment of the institution, also identify all the things that became opportunities and threats to the institution in relation to the performance of the publication.

After all the environmental factors were scanned, followed by calculating the weight and rating of Internal Factor Evaluation (IFE Matrix). It is intended to determine the position of Internal Factor Analysis Summary (IFAS) of publication's performance in Widyatama University, whether included in conditions of strong, average, or weak. Then followed by calculating the weight and rating of External Factor Evaluation (EFE Matrix). It is intended to determine the position of External Factor Analysis Summary (EFAS) of publication's performance in Widyatama University, whether included in conditions of High, Medium, or Low.

After these two steps above were done, it will get the position of the performance of publications in the form of point coordinates $(\mathrm{X}, \mathrm{Y})$ with IFAS Score at point $\mathrm{X}$ and EFAS Score at point $\mathrm{Y}$.

Then, to formulate an alternative strategy to increase the productivity of lecturer's scientific publications can be used analysis of GE Matrix, IE Matrix and TOWS Matrix $[16][17][18][19][20]$. In this study, the formulation of strategies to improve performance of publications is done by using Internal- External Matrix. After the coordinates has obtained, put into a quadrant on IE Matrix, so that the coordinates of the point can show the position of the performance of publication. Whether it is at the quadrant 1, 2, 3, 4, 5, 6, 7, 8, or 9 of IE Matrix Quadrant. Where each quadrant has a different meaning and each quadrant has a different strategy to be implemented.

In addition to using IE Matrix, the author also analyzes the state of the TOWS Matrix of publication's performance at the Widyatama University in order to obtain the formulation of strategies more accurate and comprehensive. Then both matrices will be analyzed together in order to get the appropriate formulation of strategies for improving performance publication in the future.

\section{FINDINGS \& DISCUSSIONS}

Description of the research is the description of all the data and discussion that in the end is the result of research. The discussion begins with analyzing the institution's internal and external environment to know the strengths and weaknesses of institutions in improving the performance of faculty publications, as well as analyzing institution's opportunities and threats on matters relating to the performance of lecturer's publication. The results of the analysis of the Widyatama University's internal and external environment that associated with improved lecturers publication's performance was successful observed, can be seen in Table 2 below: 
TABLE II. INTERNAL AND EXTERNAL FACTORS OF WIDYATAMA UNIVERSITY ASSOCIATED WITH PUBLICATION PERFORMANCE

\begin{tabular}{|c|c|}
\hline & Variable Indicator \\
\hline & $\begin{array}{l}\text { Strength: } \\
\text { S1- Institution's target related to lecturer's publication } \\
\text { S2- } 7 \text { Performance Appraisal Indicators of new lecturer } \\
\text { S3- Socialization of government research fund } \\
\text { S4- Institution's funding in the form of publication appreciation } \\
\text { S5- Institution's funding in the form of sponsorship } \\
\text { S6- Leaders who care about faculty research productivity } \\
\text { S7- Performance appraisal involving lecturers publication must be } \\
\quad \text { conducted in a fair and transparent }\end{array}$ \\
\hline & $\begin{array}{l}\text { Weakness: } \\
\text { W1- Institutions team that guide the lecturer in doing research } \\
\text { W2- Researching culture as a habit } \\
\text { W3- Scientific collaboration both inside and outside of the campus } \\
\text { W4- Lecturer's interest in researching } \\
\text { W5- Lecturer's academic ability in researching } \\
\text { W6 -Lecturer's financial ability in researching }\end{array}$ \\
\hline $\bar{\sigma}$ & $\begin{array}{l}\text { Opportunities: } \\
\text { O1- The increase in research funding from government } \\
\text { O2- Joint research with researchers from other countries } \\
\text { O3- Calculation of functional positions that involving publication } \\
\text { O4- Research collaboration with institutions outside the campus } \\
\text { O5- Ratings agencies that involving institutional publications }\end{array}$ \\
\hline & $\begin{array}{l}\text { Threats: } \\
\text { T1- There are several commercial publications organizers } \\
\text { T2- There are several predator publications organizers } \\
\text { T3- Punishment to the institution because of plagiarism } \\
\text { T4- Indonesia publicaton ranking is still low } \\
\text { T5- Enforcement of MEAs allow more foreign researchers who work } \\
\quad \text { in Indonesia beat domestic researchers }\end{array}$ \\
\hline
\end{tabular}

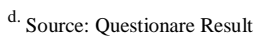

Internal factors consist of strengths and weaknesses of the Widyatama University, where there are 7 (seven) existing indicators of the institution's strength and there are 6 (six) existing indicator of the institution's weaknesses. Institution's external factors consist of opportunities and threats, opportunities and threats which each has five (5) existing indicators.

The results of in-depth interviews with key informants earn points external data to be used in the analysis of EFE in order to determine the threats and opportunities that will be faced by the Widyatama University, while the results in the form of internal data will be used in the analysis of IFE in order to identify the weaknesses and strengths Widyatama University in improving the performance of lecturer's publication.

The result of data processing based on the SWOT analysis External Factor Analysis Summary (EFAS) and Internal Factor Analysis Summary (IFAS) is as follows:
TABLE III $\quad$ EFAS \& IFAS CALCULATION

\begin{tabular}{|c|c|c|c|c|c|}
\hline Factor & $\begin{array}{l}\text { Variable } \\
\text { Indicator }\end{array}$ & Weight & $\begin{array}{c}\text { Relative } \\
\text { Weight }\end{array}$ & Rating & Score \\
\hline \multirow{2}{*}{ 胥 } & $\begin{array}{l}\text { Strength: } \\
\text { S1 } \\
\text { S2 } \\
\text { S3 } \\
\text { S4 } \\
\text { S5 } \\
\text { S6 } \\
\text { S7 }\end{array}$ & $\begin{array}{l}3,70 \\
3,70 \\
3,70 \\
3,60 \\
3,40 \\
3,40 \\
3,70 \\
\\
\mathbf{2 5 , 2 0}\end{array}$ & $\begin{array}{l}0,080 \\
0,080 \\
0,080 \\
0,078 \\
0,074 \\
0,074 \\
0,080 \\
\mathbf{0 , 5 4 5}\end{array}$ & $\begin{array}{l}4,90 \\
4,90 \\
5,10 \\
4,50 \\
4,80 \\
4,80 \\
4,30\end{array}$ & $\begin{array}{l}0,39 \\
0,39 \\
0,41 \\
0,35 \\
0,35 \\
0,35 \\
0,34 \\
\\
\mathbf{2 , 5 9}\end{array}$ \\
\hline & $\begin{array}{l}\text { Weakness: } \\
\text { W1 } \\
\text { W2 } \\
\text { W3 } \\
\text { W4 } \\
\text { W5 } \\
\text { W6 }\end{array}$ & $\begin{array}{l}3,20 \\
3,60 \\
3,40 \\
3,50 \\
3,60 \\
3,70 \\
\\
\mathbf{2 1 , 0 0}\end{array}$ & $\begin{array}{l}0,069 \\
0,078 \\
0,074 \\
0,076 \\
0,078 \\
0,080 \\
\\
\mathbf{0 , 4 5 5}\end{array}$ & $\begin{array}{l}3,70 \\
2,80 \\
2,90 \\
3,40 \\
3,30 \\
3,00\end{array}$ & $\begin{array}{l}0,26 \\
0,22 \\
0,21 \\
0,26 \\
0,26 \\
0,24 \\
\\
\mathbf{1 , 4 4}\end{array}$ \\
\hline IFAS : & & & & & 4,00 \\
\hline \multirow{2}{*}{ 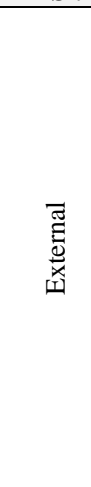 } & $\begin{array}{l}\text { Opportunit } \\
\text { y: } \\
\text { O1 } \\
\text { O2 } \\
\text { O3 } \\
\text { O4 } \\
\text { O5 }\end{array}$ & $\begin{array}{l}3,70 \\
3,50 \\
3,40 \\
2,90 \\
3,20 \\
\\
\mathbf{1 6 , 2 0}\end{array}$ & $\begin{array}{l}0,115 \\
0,109 \\
0,106 \\
0,090 \\
0,100 \\
\\
\mathbf{0 , 5 2 0}\end{array}$ & $\begin{array}{l}4,50 \\
4,10 \\
3,80 \\
3,10 \\
3,60\end{array}$ & $\begin{array}{l}0,52 \\
0,45 \\
0,40 \\
0,28 \\
0,36 \\
\\
\mathbf{2 , 0 1}\end{array}$ \\
\hline & $\begin{array}{l}\text { Threats: } \\
\text { T1 } \\
\text { T2 } \\
\text { T3 } \\
\text { T4 } \\
\text { T5 }\end{array}$ & $\begin{array}{l}2,90 \\
3,00 \\
3,40 \\
3,40 \\
2,70 \\
\\
\mathbf{1 5 , 4 0}\end{array}$ & $\begin{array}{l}0,090 \\
0,093 \\
0,106 \\
0,106 \\
0,084 \\
\\
\mathbf{0 , 4 8 0}\end{array}$ & $\begin{array}{l}3,30 \\
3,00 \\
3,90 \\
3,50 \\
3,50\end{array}$ & $\begin{array}{l}0,30 \\
0,28 \\
0,41 \\
0,37 \\
0,29 \\
\\
\\
\mathbf{1 , 6 6}\end{array}$ \\
\hline \multicolumn{5}{|l|}{ EFAS : } & 3,70 \\
\hline
\end{tabular}

\section{A. Descriptive Analysis (associated with urgency handling analysis)}

Based on the weighted scores on internal factors, found that the strength factor has weighted scores higher than the weakness. Based on a weighted score of external factors, it was found that the opportunity factor has weighted scores higher than the factor of the threat.

\section{1) Strength}

As for the institution's internal factors which have the highest weighted score (highest urgency handling), among others, are institution's targets related to lecturer's publication $(\mathrm{S} 1=3,7)$, seven performance appraisal indicators of new lecturer $(\mathrm{S} 2=3,7)$, socialization of the government research fund $(\mathrm{S} 3=3,7)$, and performance appraisal involving lecturer's publication must be conducted in a fair and transparent $(\mathrm{S} 7=3,7)$. According to some key informants at the Widyatama University, the four internal factors above require a priority seriously because it was felt quite important in increasing the productivity of publication. 
The regulatory framework included in favorable management, applicable in Widyatama University namely seven performance appraisal indicators are imposed to the new lecturer who emphasized and observed in the first two years after they've been recruited. Those indicators influence on the decision assignation of the new lecturer as a permanent lecturer at Widyatama University.

As for 7 performance appraisal indicators [21] are consisted of: (1) Equalization or increased levels of functional. (2) The Publication of scientific papers at least once in 1 academic year, either in the form of accredited journal or presented at the national seminar/ international. (3) Paper presentations in the internal seminar (at Widyatama University) at least once in 1 academic year. (4) Improved the EPT Score with minimum standards conversion TOEFL score of 525. (5) Actively participation in the institution development program. (6) Plans and realization of rising education level S3 (7) Daily tasks within the scope of the three responsibilities of higher education (tridharma perguruan tinggi). This regulation which is ultimately forced the lecturer to work, mainly in conducting scientific publications at the last 18 years.

While the lowest weighted score of the institution's strength internal factors (lowest urgency handling) are institution's funding in the form of sponsorship $(\mathrm{S} 5=3,4)$ and leaders who care about lecturer research productivity $(\mathrm{S} 6=3,4)$. Those things are associated with the institution's funding in the form of sponsorship $(\mathrm{S} 5=3,4)$. The funding policies from the institution in the form of fund's sponsorship and appreciation given to the faculty who will conduct research and publications have been run smoothly, proven could increase the interest and efforts of lecturers to realize their research and scientific publications. It has shown that the abundant resources could attract the motivation of lecturer to improve their researching ability.

Besides that, good leadership and caring leader who included in favorable government also could give good impact to the motivation and good will of the lecturer in researching. That matter could be implicated in increasing of publication performance and both things (abundant resources and favorable management) could improve the publication performance that in line with the phenomenon that had occurred in the last 18 years at Widyatama University.

\section{2) Weakness}

Weakness factor with the highest weighted score (highest urgency handling) is lecturer's financial ability in researching (W6=3,7). This condition is in accordance with the conditions in the field where the motivation of the independent research was very little, so that if the lecturer has the research proposal, then submitted to getting the funding from government, and it is not accepted, so the research was not running. Regarding to the financial ability, this reinforces previous research that research funding affects the overall publication productivity [10].

Right now, this weakness in Widyatama University is overcome with the lowest weighted score of the strength of Widyatama University, is the institution's funding in the form of sponsorship (S5) and also the institution's funding in the form of fund appreciation (S4), besides that, there's another offered solution about funding namely hibah Dikti from the government through Kemristekdikti. So that it could give the best solution to improve the publication performance of the lecturer.

The weakness factors with the lowest weighted score (lowest urgency handling) is on the institutions team that guide the lecturer in doing research $(\mathrm{W} 1=3,2)$. This weakness is relative can be overcome easily because the lecturers (particularly new lecturer) can learn from senior lecturers so that it can encourage the development of the research in Widyatama University.

\section{3) Opportunity}

As for the institution's external factors which have the highest weighted score (highest urgency handling), among others is the increase in research funding from the government $(\mathrm{O} 1=3,7)$. The state's budget through the Ministry of Research and Technology Higher Education Funding has increased significantly from year to year. Besides that Lembaga Pengelola Dana Pendidikan (LPDP) Ministry of Finance also provides a variety of funding sources, and a variety of incentives related to scientific publications for lecturers.

Lowest weighted score on the opportunity factor is researching cooperation with other institutions outside the campus (O4=2,9: Research collaboration with institutions outside the campus). Many campuses have cooperated with other campuses both inside and outside the country, but its implementation is rarely done, especially in the field of research [22].

\section{4) Threat}

Threat's factor with the highest weighted score (highest urgency handling) is punishment to institutions about plagiarism $(\mathrm{T} 3=3,4)$ and Indonesia's publication ranking is still low $(\mathrm{T} 4=3,4)$. The Ministry of National Education through the Directorate of higher education (Dikti) has issued Permendiknas number 17 of 2010 on plagiarism, for that the Directorate of Higher Education (Dikti) and Private Higher Education Coordinating (Kopertis) imposed punishment very hard against individuals or institutions who proved doing the plagiarism. If a lecturer did plagiarism in scientific work, it will be given a very heavy sanction, as well as institutions will be given moratorium sanctions due to the actions of one or several lecturers who committed plagiarism.

On the other hand, lecturers are still not fully aware of the rules and penalties for the acts of plagiarism, so this is a serious threat to higher-education institutions, especially at the Widyatama University. For this reason, it is urgently to provide insight to the lecturers, especially new lecturers. Among others the vision about plagiarism, forms of plagiarism, sanctions of plagiarism, the effects of long-term and short-term of plagiarism either to the lecturer who did plagiarism as well as to institutions that shelter.

In addition, the ranking of Indonesia scientific publication also became the highest weighted score from threat factor of SWOT (needs highest urgency handling), because from year to year, the Indonesia publication rank is still below from neighboring countries such as Malaysia and Singapore. Low rating of Indonesia's publications due to the lecturer's or researcher's ability to write scientific papers is still very low. Quality of researcher and the other factors had strong and 
significant effects on R\&D productivity [10]. And for this purpose, the institution should provide facilities to the lecturers to improve their research ability either in research methodology or statistical data processing, for example, by providing coaching or conducting research community in campus environment.

The threats factor with the lowest weighted score is on the indicator of the implementation of Asean Economic Community (MEA) or - Enforcement of MEAs allowed more foreign researchers that work in Indonesia. Beat domestic researchers $(\mathrm{T} 5=2,7)$ which came into effect at the end of December 2015 so it is still in the early stages of adaptation and not yet a threat that is so burdensome.

Besides that the presence of MEA is considered as an opportunity not regarded as a serious threat in improving scientific publications, particularly in the Widyatama University, where all the lecturers are required to have scientific publications each semester as well as all the lecturers are required to have a minimum TOEFL score of 525 , so they are ready to face the MEA.

\section{B. Internal - Eksternal Matrix Analysis}

External internal matrix is developed from models of General Electric (GE Model). Parameters used include strength internal parameters and external influences encountered. The purpose of use of this model is to acquire the business strategy at the corporate level more detailed [14]. Based on both analysis above, Widyatama University's performance publication position can be described in an Internal External Matrix (IE) as shown below:

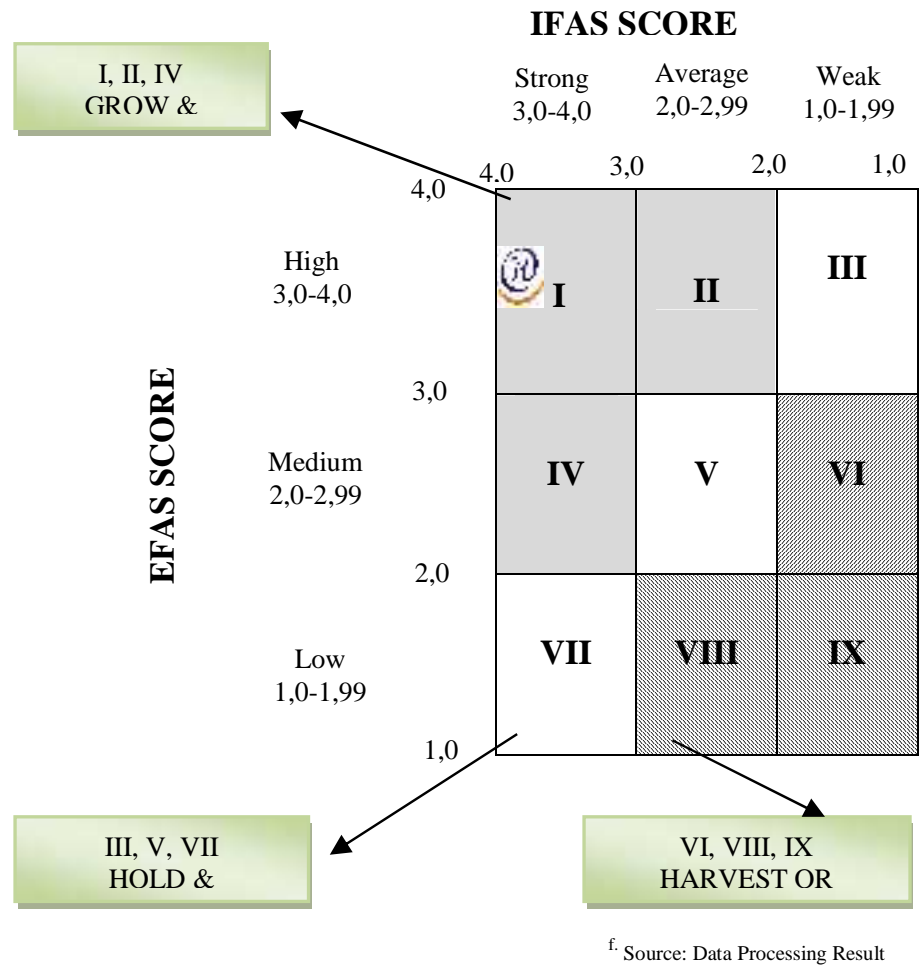

Fig. 3 Position of Widyatama University Publication Performance's
The Determination of the position of the institution in terms of research and publications at the Widyatama University, could be based on the total score of the matrix analysis of internal factors and external factors [23].

Based on the internal external matrix above, the total score of Widyatama University's publication performance position at $(4,0 ; 3,7)$ that means IFAS $=4.0$ (strong) and EFAS $=3.7$ (high). The coordinate point is in first (I) quadrant from IE matrix.

On the internal external matrix (IE Matrix), the institution's strategy that more suitable offered on the first quadrant is growth strategy with specialize in concentration through vertical integration by way of backward integration (taking over the functions of the supplier).

In matters relating to the improvements of publication performance, the largest supplier in question, here are the funders of research and publications from both internal and external. Research and publications need a relatively large cost, so that to be able to launch the process of research and publications, there are many funding opportunities that should be pursued and promoted, both by lecturer researchers themselves or by the institution.

Supplier in this case is the funders of research and publication of internal and external parties. The internal parties, the institution provides several options that can be achieved by lecturer researchers with some of the terms that have been determined.

As for the funding of the internal party can include sponsorship, funds of appreciation, as well as funds provided in the form of performance allowance for the work that has been published. Funding from the internal party has been running in the last 18 years and helps the lecturer researchers in conducting research and publication of scientific papers both nationally and internationally, both in the form of conferences and publishing scientific articles in scientific journals (journals).

The next thing that will be pursued in launching growth strategy with backward integration, is an attempt to seize external funding in this regard from the government, either in the form of research grants from Kemristekdikti or research funding $L P D P$ from Kemenkeu. For both funding have been run in the last 18 years and supported by the LPPM Widyatama University as the competent authority in the distribution.

Another thing that can be pursued in realizing the growth strategy for improving publication performance that has not been earned by Widyatama University is obtained from government funding through university's research clusters. Currently, Widyatama University still entered in the lowest cluster in the groupings, is cluster Perguruan Tinggi Binaan. In the year 2010-2012, Widyatama University gets university's research cluster binaan [24] (and gets $194^{\text {th }}$ rank). For the future, preferably looks to boost cluster from perguruan tinggi binaan become perguruan tinggi madya even perguruan tinggi utama. 
As for the meaning of the institution in cluster binaan is pioneering new research university implementation. The institution began to organize research programs taking into account of the resources owned research. Institution with honors should seek to develop research capacity in order to be able to manage research resulting in better outcome's research.

Thing that needed to be managed properly by an institution in an effort to increase university's research cluster is institution performance assessment relating to the publication. As for performance assessment of research in universities is based on 4 (four) components with different weights. The four components and their weight are for research resources at $30 \%$, $20 \%$ management research, research output by $35 \%$, and $15 \%$ revenue generating.

Institution with cluster binaan, madya, and utama is expected to spur its performance in order to improve the predicate to a higher level. For college with honors, mandiri is expected to maintain the predicate to continue to maintain and improve the performance of research. As a consequence of the establishment of this award, Ditjen Dikti will allocate performance-based research funding of research in accordance with the title earned by each institution.

\section{SWOT Matrix Analysis}

SWOT matrix can describe clearly how external opportunities and threats facing the company can be customized with its strengths and weaknesses. This matrix can produce four sets of the possibility of strategic alternatives [14]. With SWOT analysis, efforts were made to explore the ways and means of converting possible threats into opportunities, and changing weakness into strengths, and strategic plans of action were developed [25].

Based on IFAS/EFAS analysis can be described SWOT Matrix or TOWS matrix of Widyatama University's publication performance, as shown below:

\begin{tabular}{|c|c|c|}
\hline EFAS & $\begin{array}{l}\text { STRENGTHS } \\
\text { (S) } \\
\\
\\
\text { - Publication's target } \\
\text { - - Parametrs } \\
\text { - Socialization } \\
\text { government fund } \\
\text { - Appreciation fund } \\
\text { - Sponsorship fund } \\
\text { - Caring leader } \\
\text { - Fairly appraisal }\end{array}$ & $\begin{array}{l}\quad \text { WEAKNESS } \\
\quad \text { (W) } \\
\\
\\
\text { - Guidance team } \\
\text { - Researching habit } \\
\text { - Scientific } \\
\text { collaboration } \\
\text { - Lecturer's } \\
\text { interesting } \\
\text { - Lecturer's ability } \\
\text { - Lecturer's financing }\end{array}$ \\
\hline $\begin{array}{l}\text { OPPORTUNITIES } \\
\text { (O) } \\
\text { - Government funding } \\
\text { - Joint research } \\
\text { - Functional consider } \\
\text { publication } \\
\text { - Research } \\
\text { collaboration } \\
\text { - University rank } \\
\text { consider publication }\end{array}$ & $\begin{array}{l}\text { - } \begin{array}{c}\text { SO Strategy } \\
\text { poximizing the }\end{array} \\
\text { potential of } \\
\text { lecturer's research } \\
\text { and publication } \\
\text { through scientific } \\
\text { conference or } \\
\text { publications in } \\
\text { scientific articles } \\
\text { - Strive to increase } \\
\text { Widyatama } \\
\text { University's cluster } \\
\text { from binaan into } \\
\text { madya } \text { even utama }\end{array}$ & $\begin{array}{l}\text { WO Strategy } \\
\text { Foster a culture of } \\
\text { researching as a } \\
\text { habit in campus } \\
\text { environment } \\
\text { - Cultivating coaching } \\
\text { team through the } \\
\text { research community }\end{array}$ \\
\hline $\begin{array}{l}\text { Commercial } \\
\text { orgnizer } \\
\text { - Predator organizer } \\
\text { - Plagiarism sanctions } \\
\text { - Indonesia's } \\
\text { publication still low } \\
\text { - Enforcement of } \\
\text { MEA }\end{array}$ & \begin{tabular}{l}
\multicolumn{1}{c}{ ST Strategy } \\
- Improve knowledge \\
and potential quality \\
of lecturers in \\
reearching by \\
utilizing the \\
development of \\
science and \\
technology under \\
the guidance of \\
LPPM Widyatama
\end{tabular} & $\begin{array}{l}\text { WT Strategy } \\
\text { - Improving } \\
\text { knowledge and } \\
\text { lecturers' research } \\
\text { skills at Widyatama } \\
\text { University through } \\
\text { the formation of } \\
\text { research } \\
\text { communities }\end{array}$ \\
\hline
\end{tabular}

g. Source: Data Processing Result

\section{CONCLUSION \& SUGGESTIONS}

\section{A. Conclusion}

After doing environmental scanning on external and internal environment of Widyatama University related to increasing of publication performance at the last 18 years, author found that the institution's external environment on the opportunity factors more dominates positively than threats that could influence on lecturer's research and lecturer's scientific publication performance. Internally, clearly the Widyatama University has the greater strength than a weakness that can affect the performance of faculty research and scientific publication performance. It's very positive effect on the sustainability performance of research and faculty publications in the future. 
After environmental scanning has done, author could determine the position of Widyatama University related to the performance of its publication in the last 18 years by defining the coordinate point of institutional position on external internal matrix (IE Mtarix).

The position of the institution regard to the performance of its publication in the internal external matrix, are at the growth and build position (quadrant I) so that the growth strategy become more suitable to be applied in Widyatama University in order to improve the performance of research and publications as a value of a high education to be better in the future will come.

The biggest thing that significantly affected to the above circumstances, are abundant resources from both internal and external, and also favorable management of the institution that is paying great attention to the problem of faculty research and scientific publications. This is obvious managed to improve the performance of publications and WidyatamaUniversity rating's webometrics in recent years.

\section{B. Suggestions}

Viewed the empirical trend in increasing performance of publication at the Widyatama University recently, the big factors that supporting the above circumstances are abundant resources (either internal or external) and favorable management from the institution party.

Consider that, for the advancement of research and faculty publications in the future, the authors outline some proposals by first making the external and the internal matrix (IE Matrix) and TOWS Matrix as tools to formulate the best strategies that can be applied at the Widyatama University to increase in the future.

Several strategy proposals that have been formulated successfully, among others:

- Striving to improve university's research cluster at the Widyatama University which now resides in the lowest cluster "binaan" to enter the next cluster of "madya" even gets into the "utama" with the highest cluster of "mandiri". This increasing surely would be phased in accordance with the university's research performance that had been achieved. Ranked cluster is extremely implications for the provision of funding and research facilities from the government to each university according to his cluster. Further, this thing is expected to enlarge the abundant resources' factor, that clearly contributing to the increasing the publication performance in the last 18 years in Widyatama University.

- In connection with the favorable management, the significant effort can be done to improve the performance of publications in the future at the Widyatama University is creating a climate of researching as a habit of the faculty in the campus environment. This can be reinforced by the seriousness of the institution in terms of working on it.
- There are many things that can be done to create a climate of researching as a habit, among others forming a community of researchers among professors who can become a means of sharing among researchers, coaching, conducting trainings/ workshops/coaching methodology/guidance statistical data processing, etc.

\section{REFERENCES}

K. Keith, B., Layne, J.S., Babchuk, N., Johnson, “The context of scientific achievement: sex status, organizational environments, and the timing of publication on scholarship outcomes.," Soc. Forces, vol. 80, no. 4, pp. 1253-1281, 2002.

[2] Scimago, "Scimago Institutions Rankings," 2016. [Online]. Available: http://www.scimagoir.com/.

G. Abramo, C. Andrea, and D. Angelo, "Ranking research institutions by the number of highly-cited articles per scientist," J. Informetr., vol. 9, no. 4, pp. 915-923, 2015.

[4] Webometric, "Ranking Web of Universities," 2016. [Online]. Available: http://www.webometrics.info/.

G. Abramo, T. Cicero, C. Andrea, and D. Angelo, "The impact of unproductive and top researchers on overall university research performance," J. Informetr., vol. 7, no. 1, pp. 166-175, 2013.

[6] M. Antonius and W. M. Shrum, "Professional networks, scientific collaboration, and publication productivity in resource-constrained research institutions in a developing country," Res. Policy, vol. 40, no. 2, pp. 204-216, 2011.

[7] S. K. Dhillon, R. Ibrahim, and A. Selamat, "Technology in Society Factors associated with scholarly publication productivity among academic staff : Case of a Malaysian public university," Technol. Soc., vol. 42, pp. 160-166, 2015.

[8] I. J. Ibegbulam and E. U. Jacintha, "The Journal of Academic Librarianship Factors That Contribute to Research and Publication Output Among Librarians in Nigerian University Libraries," J. Acad. Librariansh., vol. 42, no. 1, pp. 15-20, 2016.

[9] N. Luo, T. D. If, and K. Hyland, "Journal of Second Language Writing Chinese academics writing for publication: English teachers as text mediators," $J$. Second Lang. Writ., vol. 33, pp. 43-55, 2016.

[10] Mulyanto, "Technology in Society Productivity of R \& D institution: The case of Indonesia," Technol. Soc., vol. 44, pp. 78-91, 2016.

[11] B. Lakitan, D. Hidayat, and S. Herlinda, "Scientific productivity and the collaboration intensity of Indonesia Universities and public $\mathrm{R} \& \mathrm{D}$ institutions: 
are there dependencies on collaborative R\&D with foreign institution?," Technol. Soc., vol. 34, pp. 227238, 20012.

[12] Mulyanto, "Performance of Indonesian R\&D Institutions: Influence of type of institutions and their funding source on R\&D productivity," Technol. Soc., vol. 38, pp. 148-160, 2014.

[13] Saaty, The Analytical Hierarchy Process and SWOT Analysis- what it is and how it is used, 9th ed. Math. Model, 1987.

[14] F. Rangkuti, ANALISIS SWOT: Teknik Membedah Kasus Bisnis. 2015.

[15] D. Ghinolfi, H. G. El, E. Borgonovi, A. Radwan, O. Laurence, H. A. Sayed, P. De Simone, M. Abdelwadoud, A. Stefani, S. S. Botros, and F. Filipponi, "A model for southern mediterranean research institute self-assessment: A SWOT analysisbased approach to promote capacity building at Theodor Bilharz Research Institute in Cairo ( Egypt )," Arab J. Gastroenterol., vol. 2014, 2014.

[16] A. H. G. Brooks and D. Henderson, "A SWOT Analysis Of Competitive Knowledge From Social Media For A Small Start-Up Business," Rev. Bus. Inf., vol. 18, no. 1, 2014.

[17] R. G. Dyson, "Strategic development and SWOT analysis at the University of Warwick," Eur. J. Oper. Res., vol. 152, pp. 631-640, 2004.

[18] H. C. and W. Huang, "Application of a quantification SWOT analytical method," Math. Comput. Model., vol. 43, pp. 158-169, 2006.

[19] K. L. G. Houben and K. Vanhoof, "A knowledgebased SWOT-analysis system as an instrument for strategic planning in small and medium sized enterprises," Decis. Support Syst., vol. 26, pp. 125135, 1999.

[20] O. Kolbina, "SWOT Analysis as a Strategic Planning Tool for Companies in the Food Industry SWOT Analysis as a Strategic Planning Tool for Companies in the Food Industry," Probl. Ecocnomic Transit., vol. 57, no. 9, pp. 74-83, 2015.

[21] U. Widyatama, "BUKU PEDOMAN DOSEN UNIVERSITAS WIDYATAMA," 2015. [Online]. Available: $\quad$ http://sdm.widyatama.ac.id/wpcontent/uploads/2015/03/Buku-Pedoman-Dosen.pdf.

[22] J. Knight, "Five Myths about Internationalisation," Int. High. Educ., vol. 62, pp. 14-15, 2011.

[23] T. L. Wheelen and J. D. Hunger, Strategic Management and Business Policy: Toward Global Sustainability. 2012.

[24] D. J. P. T. KEMENTERIAN PENDIDIKAN DAN KEBUDAYAAN, "Daftar Klaster Penelitian
Perguruan Tinggi,” 2013. [Online]. Available: http://simlitabmas.dikti.go.id/fileUpload/pengumuman/ Daftar-Klaster-Penelitian-Perguruan-Tinggi.pdf.

[25] O. Arslan and I. Deha, "SWOT analysis for safer carriage of bulk liquid chemicals in tankers," vol. 154, pp. 901-913, 2008. 